\title{
CZY WYNIKI WYBORÓW DO SEJMIKÓW PRZYBLIŻAJA WYNIKI WYBORÓW DO SEJMU? O NACJONALIZACJI REGIONALNYCH SYSTEMÓW PARTYJNYCH W POLSCE
}

\author{
DO REGIONAL ELECTIONS' RESULTS APPROXIMATE \\ TO THE PARLIAMENTARY ELECTIONS' ONES? \\ ON THE NATIONALIZATION OF REGIONAL POLITICAL \\ SYSTEMS IN POLAND
}

Tomasz Grzyb*®, Adam Gendźwiłł** 우

\begin{abstract}
ABSTRAKT
Artykuł jest próbą odpowiedzi na pytanie o podobieństwo wyników wyborów do sejmików województw i następujących po nich wyborów do Sejmu RP. Trzy nakładające się na siebie cykle wyborcze w latach 2006-2015 pozwalają na bardziej systematyczną ocenę zjawiska nacjonalizacji regionalnych systemów politycznych. Po przedyskutowaniu różnych czynników, kształtujących odmienność wyników wyborów różnych szczebli, autorzy dokonują przeglądu literatury na temat nacjonalizacji systemów partyjnych. Omawiają również konstrukcję wskaźnika niepodobieństwa, używanego do badania nacjonalizacji - i jego dekompozycję pozwalającą na dokładniejsze wskazanie przyczyn odmienności wyników wyborów różnych szczebli. Badanie
\end{abstract}

The article aims to answer the question concerning the similarity of the electoral results between regional election and subsequent parliamentary (Sejm) election in Poland. Three consecutive electoral cycles from 2006 to 2015 allow assessing systematically the scale of nationalization of regional political systems. After discussing the factors influencing the differences between the elections held at different tiers of government, the authors review the literature describing the nationalization of party systems and discuss the construction of the dissimilarity index used in the studies of party systems' nationalization. They propose a simple decomposition of dissimilarity index, which allows indicating the factors affecting the differences in electoral outcomes

* Uniwersytet Warszawski, Wydział Geografii i Studiów Regionalnych.

** Uniwersytet Warszawski, Wydział Geografii i Studiów Regionalnych. 
pokazuje, że w ciągu ostatniej dekady wzorce głosowania w wyborach regionalnych stawały się coraz bardziej odmienne od wzorców głosowania w wyborach do Sejmu. Najważniejszym czynnikiem wpływającym na zróżnicowanie wyników wyborów pozostają różnice w poparciu najbardziej stabilnych partii politycznych występujących na obu arenach rywalizacji.

Słowa kluczowe: wybory samorządowe; wybory parlamentarne; sejmiki województw; system partyjny; nacjonalizacja at different tiers. The analysis demonstrates that during the last decade the patterns of voting in regional elections have become more distinct from the patterns of voting in parliamentary elections. The main factor affecting the differences in the electoral outcomes at various tiers is the difference in the level of support for the established parties, competing in both (national and regional) electoral races.

Keywords: regional elections; parliamentary elections; regional assemblies; party system; nationalization

\section{WPROWADZENIE}

Można spotkać się z potocznym przekonaniem, że wybory do sejmików województw są swoistym „sondażem poparcia” przed wyborami do Sejmu. Analizuje się poparcie partii parlamentarnych w wyborach do sejmików, podnosząc, że samorządy województw są w dużej mierze zdominowane przez partie parlamentarne. Badania exit-poll, realizowane w dniu wyborów samorządowych i komentowane przez publicystów, również dotyczą preferencji w wyborach do sejmików województw. Są one zdecydowanie bardziej zrozumiałe dla ogólnopolskiej audiencji - komentując rozkłady preferencji, nie trzeba zagłębiać się w specyfikę lokalnych scen politycznych. Z danych PKW wynika, że w wyborach samorządowych z 2014 r. ówczesne cztery duże partie parlamentarne (PiS, PO, PSL, SLD) zdobyły ponad 95\% mandatów w sejmikach województw, ok. 70\% mandatów $\mathrm{w}$ radach powiatów ziemskich i radach miast na prawach powiatu i tylko ok. 25\% mandatów w pozostałych gminach.

Przyjmuje się nieraz milczące założenie, że im wyższy szczebel terytorialny wyborów samorządowych, tym większa ich ranga. Tymczasem $z$ sondaży opinii publicznej wiadomo, że wybory do sejmików województw są oceniane przez wyborców jako najmniej ważne, a decyzje podejmowane przez władze wojewódzkie wzbudzają najmniejsze zainteresowanie (CBOS, 2014). Zainteresowanie tym, co postanawiają władze samorządowe województw, deklaruje 27 procent Polaków, mniej niż działaniami władz powiatowych, gminnych i centralnych. Od początku istnienia trójszczeblowego samorządu terytorialnego w Polsce w wyborach samorządowych najwięcej głosów nieważnych padało w wyborach 
do sejmików województw - ta prawidłowość jest widoczna niezależnie od wyjątkowej sytuacji w wyborach z 2014 r. (Gendźwiłł i in., 2016). Odsetek głosów nieważnych to wskaźnik szczególnie wyrazisty w sytuacji, w której w wyborach równoczesnych stosowany jest ten sam system wyborczy, a elektorat głosujący w wyborach ciał przedstawicielskich różnych szczebli jest niemal dokładnie ten sam. Wielu autorów interpretuje takie wskaźniki, zwłaszcza odsetek tzw. głosów pustych (blank votes), jako oznakę alienacji i braku zainteresowania wyborców (Knack, Kropf, 2003).

Wiadomo również, że elektorat biorący udział w wyborach samorządowych jest nieco inny niż elektorat wyborów parlamentarnych. $Z$ jednej strony są to różnice w uprawnieniach do głosowania (w wyborach samorządowych nie głosują Polacy mieszkający zagranicą), a także w poziomie frekwencji wyborczej (przykładowo w wyborach samorządowych w 2014 r. wzięło udział 14,4 mln osób, a w wyborach parlamentarnych w 2015 r. - 15,6 mln osób). Systematycznie różnią się również wzorce mobilizacji i uczestnictwa w wyborach parlamentarnych i samorządowych. Zarówno $z$ danych wyborczych, jak i z danych sondażowych wynika, że w wyborach samorządowych częściej niż w wyborach parlamentarnych głosują mieszkańcy mniejszych gmin; odwrotna prawidłowość dotyczy mieszkańców największych miast (Swianiewicz, Gendźwiłł, Łukomska, Kurniewicz, 2016).

Można także przypuszczać, że nawet ci sami wyborcy ujawnią różne preferencje wyborcze w wyborach różnych szczebli. Dzieje się tak zwłaszcza wtedy, gdy porównywane wybory - $\mathrm{w}$ tym wypadku parlamentarne i samorządowe - odbywają się w znacznym odstępie czasu, który wpływa na rozkład preferencji politycznych, zwłaszcza w społeczeństwach z płytkimi i niestabilnymi identyfikacjami partyjnymi. Zgodnie z teorią wyborów drugorzędnych (second-order elections), rozwijaną również jako rama wyjaśniająca zachowania wyborcze w wyborach regionalnych i lokalnych, szczebel wyborów może stanowić znaczący kontekst wpływający w systematyczny sposób na decyzje wyborców. W literaturze opisywane są m.in. wzorce głosowania terytorialnego (Flis, 2014; Jankowski, 2016; Put, 2016), związane z personalizacją systemu wyborczego (możliwością głosowania na konkretnych kandydatów), które modyfikują wzorce głosowania partyjnego (ideologicznego).

Przytoczone powyżej argumenty nakazują z dużą ostrożnością spoglądać na „prognostyczną wartość” wyborów sejmikowych:

1. Biorą w nich udział inne elektoraty; wybory samorządowe mobilizują nieco inny zestaw wyborców niż wybory parlamentarne; 
2. Wśród wyborców biorących udział w wyborach samorządowych znaczna część (nawet kilkanaście procent otrzymujących karty do głosowania) oddaje głosy nieważne, które nie mówią nic o preferencjach politycznych ani nie przekładają się na mandaty;

3. Biorą w nich udział inne zestawy podmiotów politycznych (komitetów wyborczych), pomiędzy którymi wybór mają wyborcy; w wyborach samorządowych startują ugrupowania regionalne, które nie wystawiają kandydatów w wyborach parlamentarnych; zdarzają się również ugrupowania parlamentarne, które nie wystawiają kandydatów w wyborach samorządowych, np. ze względu na to, że powstały bezpośrednio przed wyborami parlamentarnymi (np. Nowoczesna i Kukiz'15 w 2015 r., Ruch Palikota w 2011 r.);

4. Rodzaj wyborów jest kontekstem, który może wpływać na sposób wyrażania preferencji politycznych przez wyborców - odmienne mogą być kryteria podejmowania decyzji wyborczych w głosowaniu na przedstawicieli w sejmiku województwa.

Wypadkową działania powyższych czynników są obserwowane różnice w rozkładach poparcia dla różnych ugrupowań w wyborach parlamentarnych i w wyborach do sejmików województw. Skala tych zróżnicowań, a także ich składowe, stanowią interesujące wskaźniki opisu regionalnych scen politycznych w Polsce. Rozwijając koncepcję teoretyczną nacjonalizacji regionalnych systemów partyjnych (Schakel, 2013a; 2013b), w niniejszym artykule analizujemy podobieństwo wyników wyborów do sejmików województw i wyborów parlamentarnych. Takim analizom sprzyja również kalendarz wyborczy - w ostatnich trzech samorządowych cyklach wyborczych (wyznaczanych przez wybory z 2006 r., 2010 r. i 2014 r.) odstęp dzielący wybory organów przedstawicielskich samorządu terytorialnego i wybory parlamentarne wynosił poniżej 12 miesięcy (tab. 1).

W pierwszej kolejności omówimy najważniejsze kwestie teoretyczne i metodologiczne związane z pomiarem nacjonalizacji systemów partyjnych. Następnie

Tabela 1. Terminy porównywanych wyborów samorządowych i parlamentarnych

\begin{tabular}{|c|c|}
\hline Wybory samorządowe & Wybory parlamentarne \\
\hline 12 listopada $2006 \mathrm{r}$. & 21 października $2007 \mathrm{r}$. \\
\hline 21 listopada $2010 \mathrm{r}$. & 9 października $2011 \mathrm{r}$. \\
\hline 16 listopada $2014 \mathrm{r}$. & 25 października $2015 \mathrm{r}$. \\
\hline
\end{tabular}


opiszemy dane wykorzystane w analizach i zastosowaną metodę, opartą o tzw. współczynnik niepodobieństwa (dissimilarity index) i jego dekompozycję. W dalszej części zaprezentujemy zróżnicowanie poziomu niepodobieństwa systemów partyjnych w wyborach do sejmików i do Sejmu RP w trzech kolejnych cyklach wyborczych. Na zakończenie podsumujemy rezultaty, wskazując na systematyczne różnice, oraz wskażemy potencjalne kierunki dalszych badań.

\section{NACJONALIZACJA SYSTEMÓW PARTYJNYCH}

Występowanie różnic (lub ich brak) między regionalnymi i krajowymi systemami partyjnymi nierozerwalnie związane jest z pojęciem nacjonalizacji. To pojęcie w literaturze politologicznej jest jednak niejednoznaczne. Części badaczy służy do określania poziomu zróżnicowania terytorialnego poparcia dla różnych partii politycznych (im więcej znaczących ugrupowań politycznych o wyraźnie skoncentrowanym terytorialnie poparciu, tym mniejszy poziom nacjonalizacji systemu politycznego). To podejście nawiązuje m.in. do badań nad rozwojem ogólnokrajowych scen politycznych w XX w. (Caramani, 2005) lub rozwojem europejskiego elektoratu w wyborach do Parlamentu Europejskiego. Inny sposób rozumienia nacjonalizacji, wykorzystywany również w niniejszym badaniu, utożsamia nacjonalizację z podobieństwem rozkładów preferencji partyjnych w wyborach różnych szczebli (Thorlakson, 2007; Schakel, 2013a).

U progu dwudziestego stulecia systemy partyjne, szczególnie w demokracjach zachodnioeuropejskich, cechowały się postępującą centralizacją. Trend ten powiązany był z systematycznym osłabianiem lokalnych elit i doprowadził do sytuacji, w której regionalne i lokalne systemy partyjne demokracji zachodnich lat 30. XX wieku można było uznać za w pełni znacjonalizowane (Caramani, 2005). Dodatkowym czynnikiem, katalizującym nacjonalizację systemów partyjnych, była postępująca mobilność społeczeństwa i upowszechnienie dostępu do informacji (Thorlakson, 2007). Zjawisko to okazało się na tyle silne, że zachodzące po II wojnie światowej procesy o charakterze decentralizacyjnym i federacyjnym nie były w stanie istotnie wpłynąć na zmianę lokalnych scen politycznych.

Caramani wiąże systematyczny wzrost stopnia nacjonalizacji w krajach zachodnich z procesem funkcjonalnego „wyrównywania się” sceny politycznej, wynikającego z postępu procesów centralizacyjnych w państwach oraz kształtowaniem się podziałów klasowych w związku z rozwojem gospodarczym (przede wszystkim industrializacją i urbanizacją). Z kolei Chhibber i Kollman (2004) 
stoją na stanowisku, że można wyróżnić występujące cyklicznie sekwencje okresów postępującej nacjonalizacji i regionalizacji. Autorzy uzależniają poziom nacjonalizacji od stopnia centralizacji państwa, wykazując, że naprzemienne wzmacnianie i osłabianie procesów decentralizacyjnych może prowadzić do wahań poziomu nacjonalizacji.

Golosow (2016), syntetyzując ostatnio dotychczasowe badania na temat nacjonalizacji systemów partyjnych, wskazuje grupę społecznych i instytucjonalnych czynników mających wpływ na poziom tego zjawiska. Do stymulant nacjonalizacji Golosow zalicza m.in.: demokratyczny charakter państwa, proporcjonalne ordynacje wyborcze i - w niewielkim stopniu - występowanie systemu prezydenckiego. Dowodzi także, że wysoki stopień nacjonalizacji systemu partyjnego w danym państwie jest oznaką dojrzałości tej sceny politycznej. Jako destymulanty wymienia zaś przede wszystkim: federalny charakter państwa, występowanie ordynacji większościowych i spersonalizowanego systemu wyborczego STV oraz heterogeniczność etniczną, językową i religijną. Co ciekawe, w świetle badań Golosowa stopień nacjonalizacji nie zależy od poziomu rozwoju ekonomicznego czy społecznego państwa. Spośród innych przywoływanych w literaturze czynników warto przytoczyć m.in. mającą negatywny wpływ polityczną i ekonomiczną decentralizację państwa (Thorlakson, 2007) czy ustrój prezydencki lub półprezydencki (Caramani, 2005). Warto jednak zauważyć, że w poszczególnych regionach świata zestaw czynników, odpowiadających za nacjonalizację systemów partyjnych, może cechować się pewnym zróżnicowaniem.

Pierwotnie zajmowano się przede wszystkim procesami nacjonalizacji w ukształtowanych demokracjach świata zachodniego (Jeffery, Hough, 2003; Caramani, 2005). L. Thorlakson (2007) badała różnice niepodobieństwa między wyborami krajowymi i regionalnymi w sześciu federacjach w kontekście stopnia ich decentralizacji. Ennser-Jedenastik i Hansen (2013) wykazali regionalne różnice stopnia nacjonalizacji w poszczególnych częściach Austrii na podstawie porównania wyników wyborów lokalnych i parlamentarnych. W literaturze pojawiają się również prace dotyczące Ameryki Łacińskiej (m.in. Jones, Mainwaring, 2003; Harbers, 2010). Analiza wyników wyborów z tego regionu pozwala stworzyć inny od zachodniego obraz nacjonalizacji systemów partyjnych; w Ameryce Łacińskiej, ze względu na krótsze tradycje demokratyczne i płytsze podziały polityczne, można zaobserwować m.in. większy wpływ federalnego charakteru państwa, występowania systemu prezydenckiego oraz inne niż w Europie Zachodniej skutki nacjonalizacji (wzmocnienie lokalnych elit i przejawy lokalnego autorytaryzmu; Harbers, 2010). 
Powstały również prace dotyczące regionu Europy Środkowo-Wschodniej (m.in. Bochsler, 2010; Lyons, 2010; Tiemann, 2012; Gagatek, Kotnarowski, 2017). Systemy partyjne tych państw charakteryzują się niższym niż w Europie Zachodniej poziomem nacjonalizacji, głównie z uwagi na słabą instytucjonalizację systemów partyjnych, znaczną chwiejność wyborczą oraz znaczne zróżnicowania etniczne i społeczne (Tiemann, 2012). D. Bochsler (2010) zaznacza, że na poziom nacjonalizacji w państwach postkomunistycznych w większości przypadków nie wpływają przytaczane przez innych autorów czynniki instytucjonalne (odmiennie niż np. Chhibber, Kollman, 2004).

Schakel (2013b) zwraca uwagę, że istotnym (a często zaniedbywanym) wymiarem badań nad nacjonalizacją są analizy wielopoziomowych systemów partyjnych (multi-level party systems), w których porównywane są wyniki wyborów krajowych i regionalnych, czasem również europejskich. Wielopoziomowość scen politycznych jest zagadnieniem odnoszącym się zwłaszcza do państw o charakterze federalnym, w których wyodrębnienie regionalnych układów partyjnych jest stosunkowo łatwe. Pojęcie nacjonalizacji systemów partyjnych było stosowane również w badaniach lokalnych scen politycznych. Kjaer i Elklit (2010) udokumentowali np. rosnący poziom nacjonalizacji lokalnych systemów partyjnych w duńskich gminach.

Przyjmując, że nacjonalizacja regionalnych systemów partyjnych jest określona przez stopień podobieństwa wyników wyborczych na różnych poziomach (Gendźwiłł, Żółtak, 2014), to o pełnej nacjonalizacji można mówić wtedy, gdy rozkłady preferencji partyjnych w dwóch porównywanych elekcjach - krajowej i regionalnej - na analizowanym obszarze pokrywają się. Można powiedzieć, że pojęciem odwrotnym wobec nacjonalizacji systemów partyjnych jest ich regionalizacja. Im bardziej niepodobne do siebie wspomniane wyżej rozkłady preferencji, tym bardziej zregionalizowane systemy partyjne.

Schakel, stosując wskaźnik niepodobieństwa systemów partyjnych do badań zjawiska nacjonalizacji, porównywał rozkłady preferencji partyjnych z różnych wyborów. Zwraca przy tym uwagę, że możliwe są różne konceptualizacje niepodobieństwa regionalnych i krajowych systemów partyjnych (tabela 2), innymi słowy - ich spójności terytorialnej (congruence) (Schakel, 2013b; Schakel, Dandoy, 2013).W dalszych rozważaniach stosowany będzie wskaźnik spójności terytorialnej wyborów (ostatni wiersz tabela 3), który można traktować jako wypadkową spójności terytorialnej systemu partyjnego i spójności terytorialnej elektoratu. 
Tabela 2. Różne operacjonalizacje wskaźników niepodobieństwa systemów partyjnych, opisujące różne aspekty nacjonalizacji systemów partyjnych

\begin{tabular}{|l|l|l|}
\hline \multicolumn{1}{|c|}{ Wskaźnik } & \multicolumn{2}{c|}{ Porównywane rozkłady preferencji } \\
\hline $\begin{array}{l}\text { Spójność terytorialna systemu partyjnego } \\
\text { (Party system congruence) } \\
\text { niepodobieństwo krajowych i regionalnych } \\
\text { systemów partyjnych }\end{array}$ & $\begin{array}{l}\text { Preferencje partyjne w wy- } \\
\text { borach parlamentarnych na } \\
\text { terenie kraju }\end{array}$ & $\begin{array}{l}\text { Preferencje partyjne } \\
\text { w wyborach regio- } \\
\text { nalnych na terenie } \\
\text { regionu }\end{array}$ \\
\hline $\begin{array}{l}\text { Spójność terytorialna elektoratu (Electorate } \\
\text { congruence) } \\
\text { niepodobieństwo wyników wyborów o charak- } \\
\text { terze krajowym na poziomie państwa i regionu }\end{array}$ & $\begin{array}{l}\text { Preferencje partyjne w wy- } \\
\text { torach parlamentarnych na } \\
\text { terenie kraju }\end{array}$ & $\begin{array}{l}\text { Preferencje partyjne } \\
\text { w wyborach parlamen- } \\
\text { tarnych na terenie } \\
\text { regionu }\end{array}$ \\
\hline $\begin{array}{l}\text { Spójność terytorialna wyborów (Election } \\
\text { congruence) } \\
\text { niepodobieństwo wyników wyborów krajowych } \\
\text { i regionalnych na poziomie danego regionu }\end{array}$ & $\begin{array}{l}\text { Preferencje partyjne w wy- } \\
\text { borach parlamentarnych na } \\
\text { terenie regionu }\end{array}$ & $\begin{array}{l}\text { Preferencje partyjne } \\
\text { w wyborach regio- } \\
\text { nalnych na terenie } \\
\text { regionu }\end{array}$ \\
\hline
\end{tabular}

Źródło: Schakel, Dandoy, 2013.

\section{DANE I METODA}

W niniejszej pracy posługujemy się danymi udostępnionymi przez Państwową Komisję Wyborczą. Wyniki poszczególnych wyborów zostały zagregowane na poziomie województw, a następnie wyliczono udziały procentowe poszczególnych komitetów. Kolejnym etapem było dopasowanie do siebie wyników osiąganych przez dany komitet w obu elekcjach. Mając na uwadze, iż niektóre komitety $\mathrm{w}$ jednych wyborach startują osobno, natomiast w innych tworzą koalicje, podjęliśmy decyzje o zsumowaniu wyników kilku komitetów w dwóch przypadkach:

1) zsumowano wyniki Krajowej Partii Emerytów i Rencistów oraz Sojuszu Lewicy Demokratycznej osiągnięte w wyborach do sejmików w 2010 (obie partie tworzyły koalicję w wyborach do Sejmu w 2011);

2) zsumowano wyniki SLD Lewica i Twojego Ruchu osiągnięte w wyborach do sejmików w 2014 (obie partie były częścią koalicji Zjednoczona Lewica, biorącej udział w wyborach do Sejmu w 2015).

Prosty wskaźnik niepodobieństwa, używany w dotychczasowych badaniach nacjonalizacji regionalnych systemów partyjnych (Schakel, 2013a, 2013b), określony jest wzorem: 


$$
\operatorname{dissimilarity}(\text { dis })=\frac{1}{2}\left(\sum_{i=1}^{n}\left|X_{\text {sam }}-X_{\text {sejm }}\right|\right)
$$

gdzie Xsam oznacza wynik danego komitetu w wyborach do sejmiku województwa, a Xsejm - wynik tego samego komitetu w wyborach do Sejmu, następujących po wyborach samorządowych.

Innymi słowy, uzyskana wartość jest połową sumy wartości bezwzględnych różnic rezultatów danego komitetu w wyborach regionalnych i krajowych. Wskaźnik niepodobieństwa przyjmuje wartości od 0 do 100 - wynik równy 0 oznacza całkowite podobieństwo wyników w obu elekcjach, natomiast 100 całkowite ich niepodobieństwo. $Z$ dużym uproszczeniem można więc przyjąć, że wartość 0 oznacza pełną nacjonalizację, natomiast 100 - pełną regionalizację systemu partyjnego $\mathrm{w}$ danym województwie.

W celu uszczegółowienia analizy nacjonalizacji, bazując na pomyśle E. Powell i J. Tuckera (2014) dotyczącym wskaźnika chwiejności wyborczej, dokonaliśmy dekompozycji wskaźnika, dzieląc go na trzy sumujące się składowe:

1) niepodobieństwo wynikające $z$ występowania komitetów biorących udział wyłącznie w wyborach do Sejmu,

2) niepodobieństwo wynikające $z$ występowania komitetów biorących udział wyłącznie w wyborach do sejmiku województwa,

3) niepodobieństwo wynikające $\mathrm{z}$ różnic uzyskanego poparcia między wyborami do Sejmu i do sejmiku przez komitety wystawiające listy w obu elekcjach.

Tabela 3. Hipotetyczne rozkłady głosów w porównywanych wyborach regionalnych i parlamentarnych konstrukcja indeksu niepodobieństwa

\begin{tabular}{|l|c|c|c|c|c|c|}
\hline & A & B & C & D & E & F \\
\hline $\begin{array}{l}\text { Wybory } \\
\text { regionalne }\end{array}$ & 10 & 20 & 30 & 30 & 10 & - \\
\hline $\begin{array}{l}\text { Wybory } \\
\text { parlamentarne } \\
\text { w regionie }\end{array}$ & - & 10 & 20 & 30 & 20 & 20 \\
\hline Różnica poparcia & 10 & 10 & 10 & 0 & -10 & -20 \\
\hline
\end{tabular}

Źródło: opracowanie własne. 
Aby lepiej zrozumieć ideę dekompozycji wskaźnika niepodobieństwa, warto rozważyć przykładowe rozkłady poparcia dla hipotetycznych partii A, B, C, D, E, F w danym regionie (tab. 3). Interesujący nas wskaźnik niepodobieństwa jest równy 30 (suma wartości bezwzględnych różnic poparcia podzielona przez 2), przy czym komponent wynikający ze startu regionalnego ugrupowania jest równy 5 , komponent wynikający ze startu ugrupowania $\mathrm{F}$ wyłącznie w wyborach sejmowych jest równy 10, a komponent wynikający ze zmian poparcia partii startujących w obu elekcjach jest równy 15.

\section{WYNIKI}

Na ryc. 1 przedstawione są uśrednione wskaźniki niepodobieństwa dla całego kraju w trzech porównywanych kolejno parach wyborów. Jak widać, wartość wskaźnika w badanym okresie oscyluje między 20 a 35 i charakteryzuje się tendencją wzrostową. Oznacza to, że w ciągu ostatniej dekady niepodobieństwo pomiędzy wynikami wyborów do sejmików i wynikami wyborów do Sejmu rosło.

Można zauważyć, że za ponad połowę wartości wskaźnika niepodobieństwa odpowiada trzecia składowa - wynikająca z różnic poparcia komitetów „stabilnych” partii, tzn. biorących udział w obu głosowaniach. W kolejnych parach wyborów rosło jednak znaczenie komponentu pierwszego, związanego z występowaniem komitetów wyłącznie w wyborach do Sejmu - w ostatnim czasie pojawiło się bowiem kilka ugrupowań, które powstawały bezpośrednio przed wyborami parlamentarnymi. Wartość komponentu związanego ze startami komitetów stricte regionalnych (biorących udział tylko w wyborach do sejmików) jest względnie stała i wynosi ok. 4-4,5 (jest to zatem kilkanaście procent całości niepodobieństwa między wyborami regionalnymi a ogólnokrajowymi).

Jak już wspomniano, za przyrost wartości wskaźnika niepodobieństwa odpowiada przede wszystkim jego pierwsza składowa, której wartość między dwiema skrajnymi parami analizowanych głosowań wzrosła blisko dziesięciokrotnie. Tak znaczna dysproporcja jest konsekwencją chwiejności „podażowej” strony ogólnopolskiego systemu partyjnego. O ile między 2006 a 2007 rokiem nie doszło do znaczących zmian w zestawie najważniejszych partii rywalizujących o władzę, o tyle przed kolejnymi wyborami parlamentarnymi pojawiały się listy nowych ugrupowań. W 2011 r. były to przede wszystkim partie Polska Jest Najważniejsza oraz Ruch Palikota. Jeszcze intensywniej widać to w 2015 r. Istotne odsetki głosów 


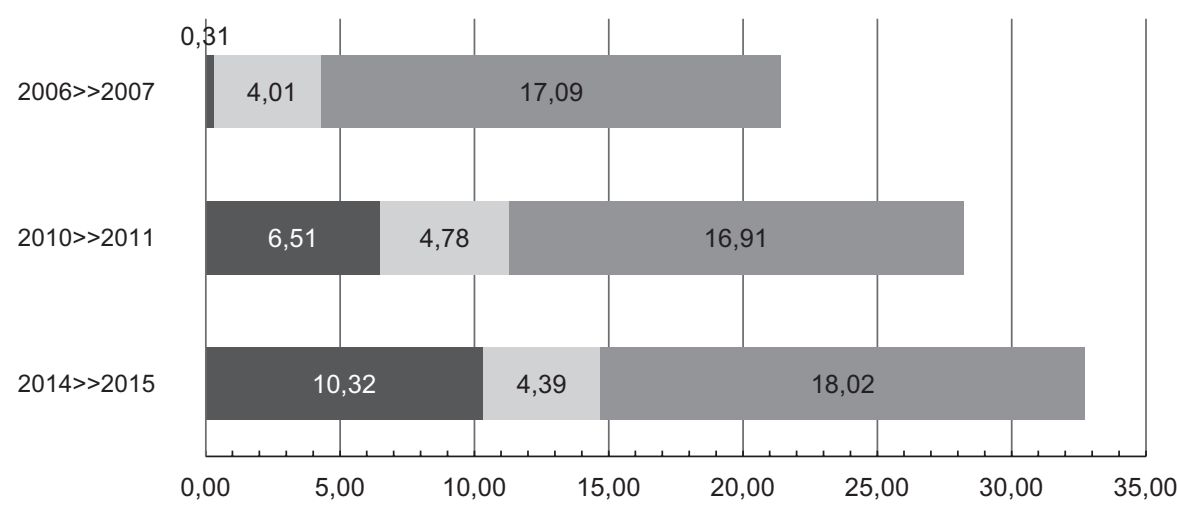

niepodobieństwo wynikające z występowania komitetów biorących udział wyłącznie w wyborach do Sejmu

$\square$ niepodobieństwo wynikające z występowania komitetów biorących udział wyłącznie w wyborach do sejmiku województwa

$\square$ niepodobieństwo wynikające z różnic uzyskanego poparcia między wyborami do Sejmu i dosejmiku przez komitety wystawiające listy w obu elekcjach

Ryc. 1. Uśrednione wartości zdekomponowanego wskaźnika niepodobieństwa dla par głosowań*

Źródło: opracowanie własne.

* średnia ważona - waga: populacja województw odpowiednio w 2007, 2011 i 2015

zdobyły: Partia Razem, Partia KORWiN, Nowoczesna Ryszarda Petru oraz ruch Kukiz'15 - ugrupowania, niezakorzenione w samorządzie regionalnym.

Analizując wartości wskaźnika niepodobieństwa dla pierwszej pary głosowań (2006, 2007), można zaobserwować pewne wzorce przestrzenne (ryc. 2). Najwyższe wartości wskaźnik przyjmuje w województwach centralnych i wschodnich - powyżej 25, w świętokrzyskim - powyżej 30; największym podobieństwem (nacjonalizacją) cechują się zaś wyniki w województwie pomorskim i małopolskim (wartości poniżej 15). Dysproporcje te wynikały przede wszystkim z regionalnego zróżnicowania zmian poparcia dla dwóch największych partii - PiS i PO. We wschodniej i centralnej części kraju przyrost poparcia dla tych komitetów o wielkości od kilku do blisko dwudziestu punktów procentowych (p. proc.) był przede wszystkim konsekwencją wzrostu poparcia dla PiS i spadku poparcia dla koalicjantów tej partii (Samoobrony i Ligi Polski Rodzin), a także słabszego niż w wyborach samorządowych wyniku PSL w wyborach parlamentarnych (co jest widoczne szczególnie w przypadku woj. świętokrzyskiego) i w mniejszym stopniu lewicowej koalicji LiD. W zachodniej i południowej części kraju za 


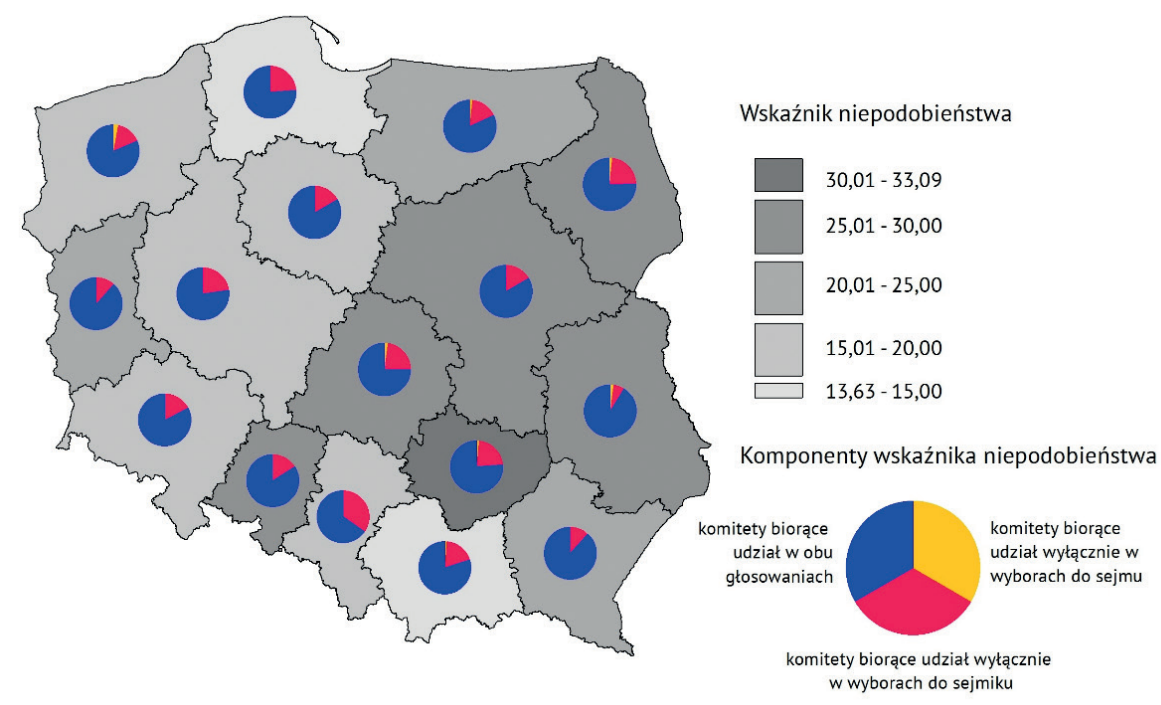

Ryc. 2. Regionalne zróżnicowanie wartości wskaźnika niepodobieństwa między wyborami w 2006 i 2007 roku

Źródło: opracowanie własne.

niepodobieństwo wyników odpowiadał przede wszystkim wzrost poparcia dla PO (w mniejszym stopniu PiS), przy spadku poparcia dla Samoobrony i LPR.

Biorąc pod uwagę komponenty wskaźnika, za jego wartość odpowiada przede wszystkim niepodobieństwo wyników uzyskiwanych przez komitety biorące udział w obu głosowaniach - jego udział w każdym z województw przekracza 50\%, a w $14 \mathrm{z}$ nich (oprócz wielkopolskiego i śląskiego) - 75\%. Udział komitetów biorących udział wyłącznie w wyborach do Sejmu w 2007 r. był nieznaczny i zauważalny jedynie w nielicznych województwach (m.in. zachodniopomorskim, łódzkim, warmińsko-mazurskim i lubelskim). Komitety biorące udział tylko w wyborach do sejmików generowały od około 10-15 \% (lubelskie, lubuskie, podkarpackie) do około 35\% (śląskie, wielkopolskie) wartości wskaźnika niepodobieństwa. W przywołanych województwach za tak wysokie udziały w głosach oddawanych w wyborach samorządowych odpowiada ponadprzeciętna aktywność regionalnych ugrupowań politycznych (np. Ruch Autonomii Śląska), niestartujących w wyborach parlamentarnych lub uzysku- 
jących w nich znikome poparcie. Wyjątkiem jest Mniejszość Niemiecka, której przedstawiciele skutecznie biorą udział zarówno w wyborach regionalnych, jak i krajowych, uzyskując $\mathrm{w}$ województwie opolskim w analizowanym okresie od około 8\% (wybory parlamentarne) do 15-18\% głosów (wybory do Sejmiku).

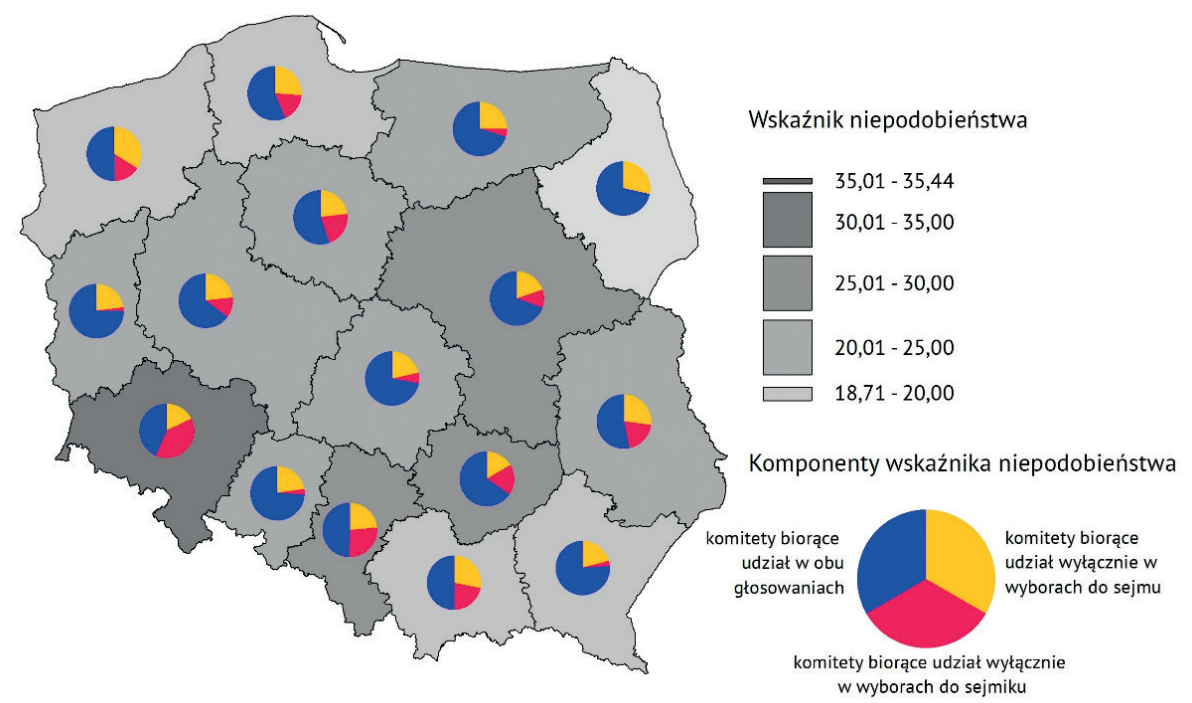

Ryc. 3. Regionalne zróżnicowanie wartości wskaźnika niepodobieństwa między wyborami w 2010 i 2011 roku

Źródło: opracowanie własne.

W przypadku drugiej pary głosowań $(2010,2011)$ trudno wskazać jakikolwiek wzorzec przestrzenny wskaźnika niepodobieństwa na szczeblu województw. Wskaźnik osiągnął najwyższą wartość w województwach dolnośląskim (ponad 35) oraz mazowieckim, świętokrzyskim i śląskim (nieco ponad 30), zaś najniższą - w woj. podlaskim (niespełna 20). Na zróżnicowanie wysokości wskaźnika w poszczególnych regionach miały ponownie wpływ przede wszystkim zmiany poparcia dla najważniejszych komitetów. Podobnie jak w poprzedniej parze analizowanych wyborów, między 2010 i 2011 r. doszło do wzrostu poparcia dla PO i PiS oraz spadku udziału PSL oraz SLD. Dodatkowym czynnikiem wzmacniającym niepodobieństwo było wspomniane już wystawienie list w wyborach parlamentarnych przez dwa nowe ugrupowania - PJN i Ruch Palikota, które w skali kraju uzyskały odpowiednio 2,2\% i 10,0\% głosów. W przypadku woje- 
wództwa dolnośląskiego tak wysoka wartość wskaźnika związana jest z sukcesem w wyborach do sejmiku ugrupowania Rafała Dutkiewicza, wieloletniego prezydenta Wrocławia. Niska wartość wskaźnika w województwie podlaskim jest zaś konsekwencją niewielkich (w porównaniu do innych regionów) różnic między wynikami PiS i PO w poszczególnych głosowaniach oraz braku w nich istotnych ugrupowań regionalnych.

Podobnie jak w przypadku pierwszej pary głosowań, za wysokość wskaźnika niepodobieństwa w poszczególnych województwach odpowiadają przede wszystkim różnice wyników wyborczych ugrupowań biorących udział w obu głosowaniach. Ich znaczenie jednak zauważalnie spadło - stanowią one od niespełna $40 \%$ (dolnośląskie) do około 70\% wartości wskaźnika (lubuskie, opolskie, podkarpackie). Wpływ nowych partii ogólnokrajowych - komitetów, które wzięły udział wyłącznie w wyborach do Sejmu - uległ wyraźnemu zwiększeniu. W każdym z województw ten komponent nacjonalizacji regionalnych systemów partyjnych stanowi około $25 \%$ wskaźnika, a w przypadku województwa zachodniopomorskiego - blisko $1 / 3$. Wpływ partii regionalnych, tzn. komitetów wystawiających listy wyłącznie w wyborach do sejmiku, w większości województw ma znaczenie zbliżone do 10-25\%; wyjątkami są województwa: podlaskie i lubuskie (1-2\%; nie było tam praktycznie znaczących ugrupowań regionalnych) oraz dolnośląskie (niespełna 40\%; głównie za sprawą komitetu dolnośląskich samorządowców firmowanego przez R. Dutkiewicza).

W trzeciej analizowanej parze głosowań (2014-2015) różnice między wartościami wskaźnika niepodobieństwa w poszczególnych regionach uległy zauważalnemu zmniejszeniu. Najniższe wartości (niespełna 30) przyjmuje on w województwach: pomorskim, małopolskim i podkarpackim. Największe podobieństwo wyników wyborów do sejmików i wyników wyborów do Sejmu występuje więc w regionach, które uchodziły za „bastiony” dwóch najważniejszych wówczas partii na ogólnopolskiej scenie politycznej: PiS (małopolskie, podkarpackie) oraz PO (pomorskie). Zmiany poparcia dla tych ugrupowań między wyborami samorządowymi i sejmowymi (w porównaniu do innych regionów) w tych województwach były stosunkowo niewielkie. Wysoką wartość wskaźnika w województwie świętokrzyskim (nieco ponad 40) można z kolei tłumaczyć zdecydowanie większym niż w innych regionach spadkiem poparcia PSL między głosowaniami ( $\mathrm{z} 46 \%$ w wyborach sejmikowych do niespełna $10 \%$ w wyborach do Sejmu). Wpływ na wzrost wartości wskaźnika miało również pojawienie się nowych, ogólnopolskich ugrupowań (m.in. Nowoczesnej Ryszarda Petru czy ruchu Kukiz'15). 


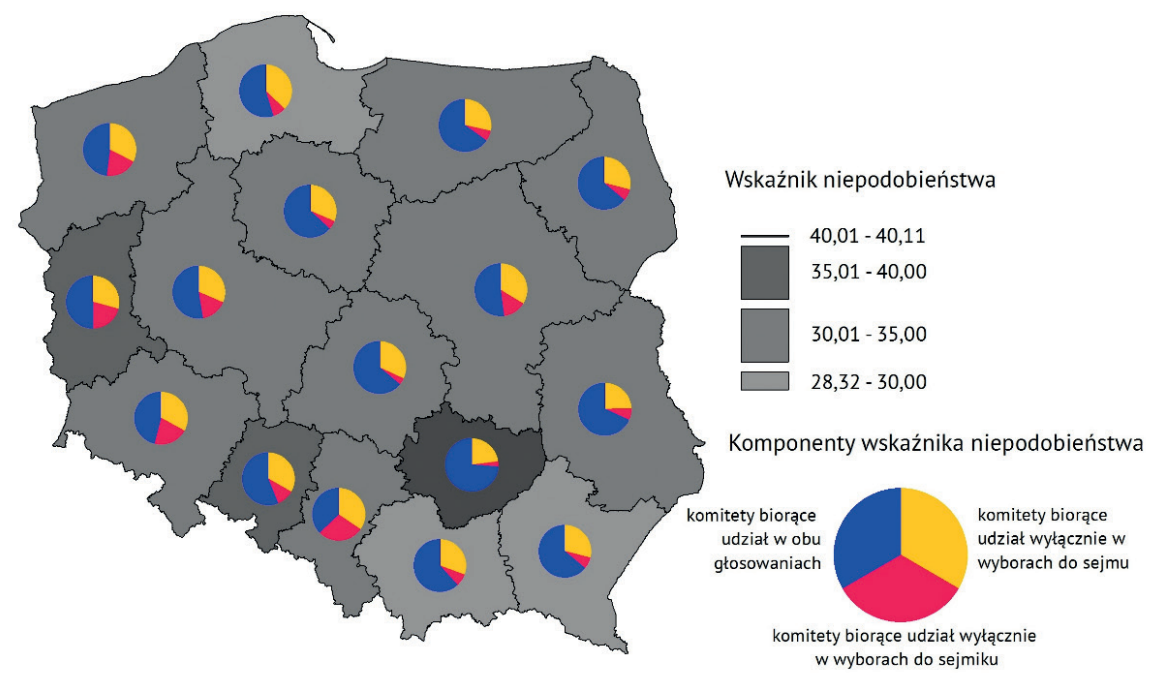

Ryc. 4. Regionalne zróżnicowanie wartości wskaźnika niepodobieństwa między wyborami w 2014 i 2015 roku

Źródło: opracowanie własne.

Analiza komponentów wskaźnika niepodobieństwa pozwala stwierdzić, że za wysokość wskaźnika w poszczególnych województwach odpowiada przede wszystkim niepodobieństwo wyników ugrupowań startujących w obu głosowaniach. Komponent ten stanowi od 35\% (śląskie) do blisko 75\% (świętokrzyskie) wartości wskaźnika. Drugą co do znaczenia składową jest udział komitetów biorących udział tylko w wyborach parlamentarnych - w większości województw komponent ten odpowiadał za około 30-35\% wartości wskaźnika niepodobieństwa. Z badań sondażowych wiadomo, że poparcie dla niektórych z nowo powstałych partii ogólnopolskich było efektem odpływu części elektoratu ze starszych, bardziej stabilnych partii (np. poparcie Nowoczesnej przez część dawnych wyborców PO). Jednocześnie trzeba zauważyć, że trzecia analizowana para wyborów charakteryzuje się zdecydowanym spadkiem znaczenia ugrupowań regionalnych, wystawiających listy tylko w wyborach do sejmików - komponent ten stanowi od zaledwie kilku (we wschodniej i centralnej części Polski) do 15-30\% (na Mazowszu i w województwach zachodnich) wartości wskaźnika.

Podsumowując, można zauważyć, że wskaźniki niepodobieństwa wyników wyborów do sejmików i następujących po nich wyborów do Sejmu rosły w ostatniej dekadzie prawie we wszystkich województwach (tab. 4). Do województw 
o systematycznie wyższych wskaźnikach niepodobieństwa należą: świętokrzyskie, mazowieckie i opolskie. W analizowanym okresie wyniki wyborów do sejmików systematycznie najbardziej przypominały wyniki wyborów do Sejmu w województwach pomorskim i małopolskim.

Tabela 4. Wskaźniki niepodobieństwa wyników wyborów do sejmików i do Sejmu RP dla 16 województw, 2006-2015

\begin{tabular}{|c|c|c|c|c|}
\hline & $\mathbf{2 0 0 6 - 2 0 0 7}$ & $\mathbf{2 0 1 0 - 2 0 1 1}$ & $\mathbf{2 0 1 4 - 2 0 1 5}$ & Średnia \\
\hline dolnośląskie & $\mathbf{1 5 , 5 5}$ & $\mathbf{3 5 , 4 4}$ & 33,62 & 28,20 \\
\hline kujawsko-pomorskie & $\mathbf{1 8 , 6 3}$ & $\mathbf{2 8 , 5 1}$ & 30,70 & 25,95 \\
\hline lubelskie & 26,64 & 25,80 & 34,19 & 28,88 \\
\hline lubuskie & 20,26 & 28,96 & 39,80 & 29,67 \\
\hline łódzkie & 26,11 & 28,32 & 30,51 & 28,31 \\
\hline małopolskie & 14,39 & 20,52 & 29,71 & 21,54 \\
\hline mazowieckie & 27,47 & 30,74 & 32,63 & 30,28 \\
\hline opolskie & 26,43 & 27,72 & 35,34 & 29,83 \\
\hline podkarpackie & 22,29 & 21,71 & 28,78 & 24,26 \\
\hline podlaskie & 29,23 & 18,71 & 30,36 & 26,10 \\
\hline pomorskie & 13,63 & 24,38 & 28,32 & 22,11 \\
\hline śląskie & 17,62 & 30,36 & 34,53 & 27,50 \\
\hline świętokrzyskie & 33,09 & 32,86 & 40,11 & 35,35 \\
\hline warmińsko-mazurskie & 23,32 & 27,39 & 34,85 & 28,52 \\
\hline wielkopolskie & 19,43 & 28,19 & 34,91 & 27,51 \\
\hline zachodniopomorskie & 17,82 & 23,71 & 32,59 & 24,71 \\
\hline
\end{tabular}

Źródło: PKW, obliczenia własne.

Jeszcze inny sposób podsumowania wyników analiz podobieństwa wyników wyborów do sejmików i wyborów do Sejmu przedstawia tab. 5. Dla czterech najbardziej stabilnych partii politycznych w analizowanym okresie (PiS, PO, PSL, SLD) należy wyliczyć różnice między poparciem w sparowanych ze sobą głosowaniach. W analizowanym okresie można zaobserwować systematyczne wzorce zmian poparcia, które pomiędzy województwami rzadko różnią się kierunkiem, natomiast różnią się intensywnością.

Wyniki pokazują, że PiS za każdym razem miał zdecydowanie wyższy wynik w wyborach do Sejmu niż w wyborach do sejmików województw. Różnice między 2014 a 2015 r. sięgały nawet powyżej 10 p. proc. Jeszcze większe różnice 


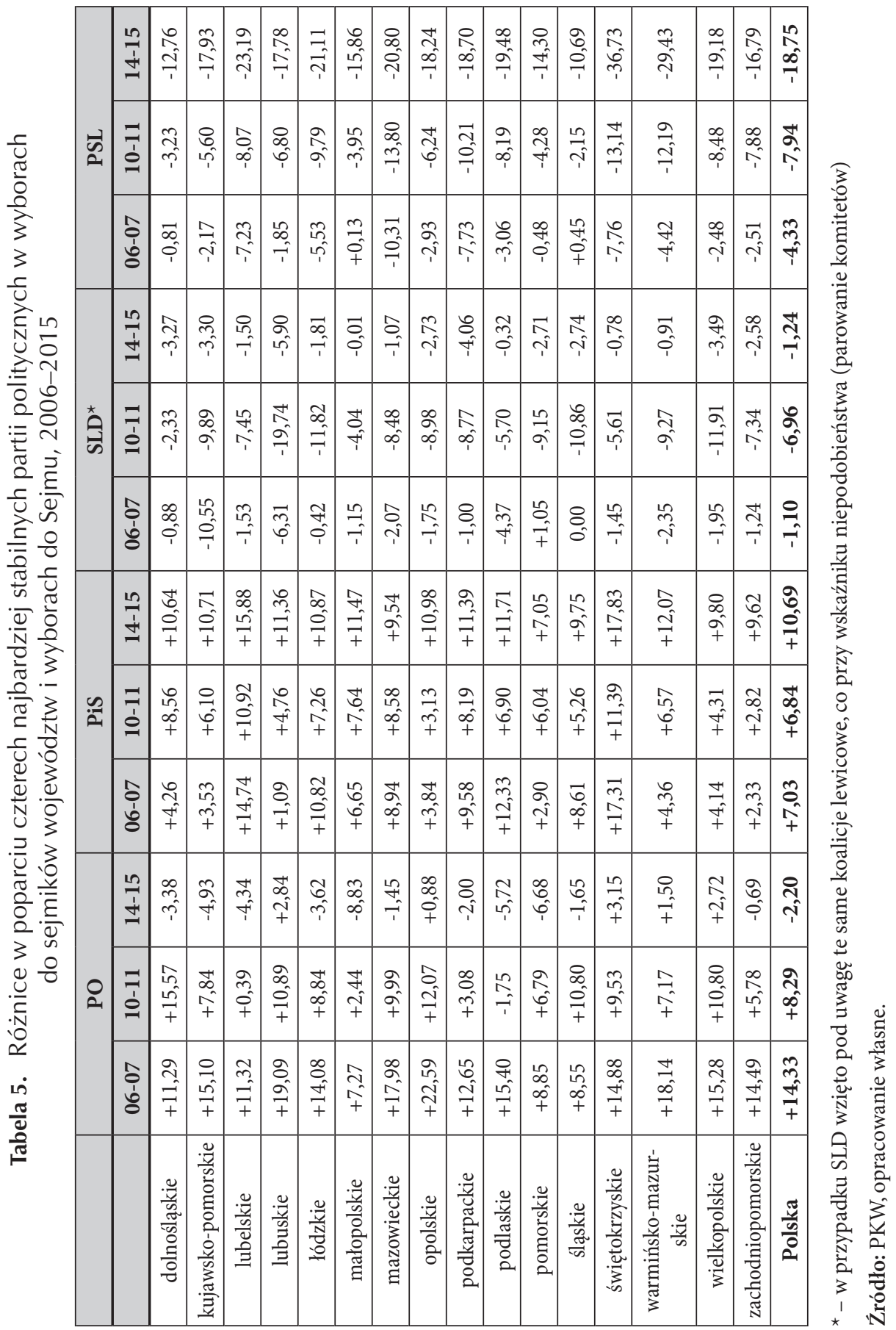


można zaobserwować między wyborami z 2006 i 2007 r.; w przypadku PO przekraczają nawet 15 p. proc. W ostatnim okresie widać wyraźnie osłabienie pozycji PO (można wiązać to ze spadkową tendencją poparcia między 2014 a 2015 r., ale też powstaniem partii Nowoczesna, która nie brała udziału w wyborach samorządowych z 2014 r.; zsumowanie poparcia dla N. i PO w 2015 r. skutkowałoby zmniejszeniem różnic w poziomie poparcia i w większości województw w Polsce mielibyśmy do czynienia z przyrostem poparcia dla $\mathrm{PO}+\mathrm{N}$. między 2014 a 2015 r.).

W przypadku SLD i - w szczególności - PSL różnice w poziomie poparcia wskazują na odwrotny wzorzec: większe poparcie te partie notowały w wyborach samorządowych niż w bezpośrednio następujących po nich wyborach parlamentarnych. W przypadku PSL bardzo wyraźny spadek poparcia między 2014 a 2015 r. może być związany z tzw. „efektem książeczki” w wyborach do sejmików z 2014 r. - jest dość prawdopodobne, że partia ta, umieszczona na pierwszej stronie zbroszurowanych kart wyborczych, otrzymywała dodatkowe głosy wyborców. Wyniki te mogą sugerować, że te partie, określane w literaturze jako partie-sukcesorki (Grzymała-Busse, 2002), mając dość dobrze rozbudowaną infrastrukturę terenową - niezależnie od niskiego poziomu poparcia $\mathrm{w}$ wyborach ogólnokrajowych - dysponują względnie bardziej atrakcyjnymi kandydatami $\mathrm{w}$ wyborach samorządowych lub bardziej zmobilizowanymi elektoratami.

\section{PODSUMOWANIE}

Przeprowadzone w pracy badania wykazały, że wraz z upływem czasu niepodobieństwo krajowych i regionalnych systemów partyjnych w Polsce zwiększało się. Oznacza to, że w ciągu ostatniej dekady poziom nacjonalizacji wojewódzkich scen politycznych ulegał stopniowemu zmniejszeniu, głównie ze względu na wahania poparcia dla stabilniejszych partii politycznych. Wniosek ten koresponduje $z$ analizami zaprezentowanymi przez Gagatka i Kotnarowskiego (2017), choć autorzy ci - biorąc pod uwagę serię pomiarów od 1998 r. - ostrożniej wypowiadają się na temat postępów regionalizacji systemu partyjnego.

Zmiany poziomu nacjonalizacji systemu partyjnego są możliwe do zaobserwowania na obszarze całego kraju, jednak dynamika tego zjawiska jest zróżnicowana regionalnie. Nasza analiza pokazuje, że zmianie ulegało znaczenie poszczególnych komponentów wskaźnika nacjonalizacji. Spośród trzech wyodrębnionych komponentów nacjonalizacji w analizowanym okresie rosło 
znaczenie nowych partii ogólnokrajowych, które nie brały udziału w wyborach regionalnych poprzedzających parlamentarne. Fakt, że zarówno w wyborach do Sejmu w 2011 r., jak i w 2015 r. nowe partie w systemie uzyskiwały znaczące odsetki głosów, zwiększał niepodobieństwa między ogólnokrajową a regionalnymi scenami politycznymi.

Względne znaczenie ugrupowań regionalnych, biorących udział tylko w wyborach samorządowych, było niewielkie w skali całego kraju. Ten komponent miał jednak istotne znaczenie w wybranych województwach i mógł znacząco zmniejszać nacjonalizację regionalnego systemu partyjnego w sejmiku województwa. Dla wzrostu niepodobieństwa zdecydowanie ważniejsze jest powstawanie ugrupowań wyłącznie ogólnopolskich niż wyłącznie regionalnych. Pojawienie się regionalnego ugrupowania wydaje się trudne do przewidzenia w sytuacji, w której „próg wejścia” do rywalizacji wyborczej w wyborach regionalnych jest niewielki.

W naszych analizach pokazaliśmy też, że największy udział w wartościach wskaźnika niepodobieństwa, będącego miarą stopnia nacjonalizacji, mają przede wszystkim regionalne wahania poparcia dla najważniejszych ugrupowań ogólnopolskich (głównie PiS, PO oraz PSL).

Systematyczne zwiększanie się niepodobieństwa między wynikami wyborów samorządowych i parlamentarnych zmniejsza zatem szanse na postrzeganie tych pierwszych jako wiarygodnego sondażu przed wyborami parlamentarnymi. Osoby postrzegające wybory samorządowe jako „próbę sił” przed wyborami sejmowymi powinny wziąć pod uwagę zastrzeżenia, które wskazujemy we wstępie do niniejszego artykułu, a także proste analizy „międzypoziomowej chwiejności wyborczej”. Kalendarz wyborczy sprawia, że w roku 2019 będzie można (na podstawie czwartej pary elekcji) sprawdzić, czy dostrzeżony w badaniach trend będzie miał swoją kontynuację.

Powyższa praca jest zaledwie przyczynkiem do studiów nad nacjonalizacją systemów partyjnych w kontekście polskim. Z pewnością warte dalszych analiz są czynniki wyjaśniające zróżnicowanie zachowań wyborczych, wzorców głosowania pomiędzy wyborami różnych szczebli. Dostępne dane wyborcze pozwalają uczynić takie analizy dużo dokładniejszymi, a także odnieść je do wyborów ciał przedstawicielskich na innych szczeblach samorządu (powiaty, gminy). Możliwe jest prowadzenie analiz na poziomie gmin, okręgów wyborczych, a nawet (z pewnymi ograniczeniami) na poziomie obwodów głosowania. 
BibliOgRAFIA:

Bochsler, D. (2010). The Nationalisation of Post-Communist Party Systems. Europe-Asia Studies, 62, 807-821. DOI: 10.1080/09668136.2010.481387.

Caramani, D. (2005). The Formation of National Party Systems in Europe: A Comparative-Historical Analysis. Scandinavian Political Studies, 28, 295-322.

CBOS. (2014). Ranga wyborów i zainteresowanie decyzjami władz różnych szczebli. Komunikat z badań nr 148/2014. Oprac. A. Gendźwiłł.

Chhibber, P., Kollman, K. (2004). The Formation of National Party Systems: Federalism and Party Competition in Canada, Great Britain, India and the United States. Princeton: Princeton University Press.

Ennser-Jedenastik, L., Hansen, M.E. (2013). The Contingent Nature of Local Party System Nationalisation: The Case of Austria 1985-2009. Local Government Studies, 39, 777-791. DOI: 10.1080/03003930.2012.675328.

Flis, J. (2014). Złudzenia wyboru: społeczne wyobrażenia i instytucjonalne ramy w wyborach do sejmu i senatu. Kraków: Wydawnictwo Uniwersytetu Jagiellońskiego.

Gagatek, W., Kotnarowski, M. (2017). Poland: Nationalization Despite Fear of Regionalization. W: A. Schakel (red.), Regional and National Elections in Eastern Europe. Territoriality of the Vote in Ten Countries (129-153). Houndsmills: Palgrave Macmillan. DOI: 10.1057/978-1-137-51787-6_6.

Gendźwiłł, A., Cześnik, M., Flis, J., Haman, J., Materska-Sosnowska, A., Michalak, B., Pietrzyk, P., Zbieranek, J. (2016). Nieważne głosy, ważny problem. Wyniki badania kart do głosowania $z$ wyborów do sejmików województw 2014. Warszawa: Fundacja im. Stefana Batorego.

Gendźwiłł, A., Żółtak, T. (2014). It Is All About Dissimilarity: Party System Characteristics and Their Proper Measurement. Paper presented at the $72^{\text {nd }}$ Annual Conference of Midwest Political Science Association. Pobrany z: https://www.ssoar.info/ssoar/ handle/document/58500.

Golosov, G.V. (2016). Factors of Party System Nationalization. International Political Science Review, 37, 246-260. DOI: 10.1177/0192512114552864.

Harbers, I. (2010). Decentralisation and the Development of Nationalized Party Systems in New Democracies: Evidence From Latin America. Comparative Political Studies, 43, 606-627. DOI: 10.1177/0010414008330285.

Jankowski, M. (2016). Voting for Locals: Voters' Information Processing Strategies in Open-List PR Systems. Electoral Studies, 43, 72-84. DOI: 10.1016/j.electstud.2016.06.0050261-3794.

Jeffery, C., Hough, D. (2003). Regional Elections in Multi-Level Systems. European Urban and Regional Studies, 10, 99-212. DOI: 10.1177/09697764030103002.

Jones, M., Mainwaring, S. (2003). The Nationalisation of Parties and Party Systems: An Empirical Measure and an Application to the Americas. Party Politics, 9, 139-166. DOI: $10.1177 / 13540688030092002$.

Jurado, I, (2014). Party System Nationalisation and Social Spending. European Journal of Political Research, 53, 288-307. DOI: 10.1111/1475-6765.12035. 
Kjaer, U., Elklit, J. (2010). Local Party System Nationalisation. Does Municipal Size Matters? Local Government Studies, 36, 425-444. DOI: 10.1080/03003931003730451.

Knack, S., Kropf, M. (2003). Voided Ballots in the 1996 Presidential Election: A County Level Analysis. Journal of Politics, 65, 881-897. DOI: 10.1111/1468-2508.00217.

Lyons, P. (2010). Party System Nationalisation and Non-uniform Vote Switching. Evidence from the Czech Republic. Czech Sociological Review, 3, 375-399. DOI: $10.2307 / 41132864$.

Powell, E.N., Tucker, J. (2014). Revisiting Electoral Volatility in Post-Communist Countries: New Data, New Results and New Approaches. British Journal of Political Science, 44, 123-147. DOI: 10.1017/S0007123412000531.

Put, G. (2016). Determinants of Geographical Representation on Candidate Lists in Flexible-List Systems: Lessons from the Belgian Case. Politics, 36, 180-196. DOI: 10.1111/1467-9256.12089.

Schakel, A.H. (2013a). Congruence Between Regional and National Elections. Comparative Political Studies, 46, 631-662. DOI: 10.1177/0010414011424112.

Schakel, A.H. (2013b). Nationalisation of Multilevel Party Systems: A Conceptual and Empirical Analysis. European Journal of Political Research, 52, 212-236. DOI: 10.1111/j.1475-6765.2012.02067.x.

Schakel, A.H., Dandoy, R. (2013). Introduction: Territoriality of the Vote: A Framework for Analysis. W: R. Dandoy, A.H. Schakel (red.). Regional and National Elections in Western Europe. Territoriality of the Vote in Thirteen Countries (1-26). Houndsmills: Palgrave Macmillan.

Swianiewicz, P., Gendźwiłł, A., Łukomska, J., Kurniewicz, A. (2016). Rozmiar gmin i powiatów a sprawność ich funkcjonowania. Hipotezy wielkoludów i liliputów. Warszawa: Wyd. Naukowe Scholar.

Thorlakson, L. (2007). An Institutional Explanation of Party System Congruence: Evidence from Six Federations. European Journal of Political Research, 46, 69-95. DOI: 10.1111/j.1475-6765.2006.00647.x.

Tiemann, G. (2012). The Nationalisation of Political Parties and Party Systems in Post-Communist Eastern Europe. Communist and Post-Communist Studies, 45, 77-89. DOI:10.1016/j.postcomstud.2012.02.009. 